\title{
Metaphor and Simile in English Context: Do They Know the Differences?
}

\author{
Agnes S. Simanjuntak \\ Universitas Lancang Kuning, Pekanbaru, Indonesia \\ anneagnesiaelviws@gmail.com
}

\section{ARTICLE HISTORY}

Received : 2019-08-03

Revised : 2019-08-22

Accepted : 2019-08-31

\section{KEYWORDS}

Metaphor

Simile

English context

Differences

\begin{abstract}
The present research tries to explore and find out the students understanding on selected metaphor and simile in English context at the sixth semester of English Education Department in Universitas Lancang Kuning. This descriptive quantitative research involves 38 students as it samples selected from two classes in total. This research was conducted on May, 2019. The instruments used to collect the data were test which consisted of 40 items. The result from the test revealed the understanding on these two topics are fair, metaphor $(62,63)$ and simile $(60,92)$. This data seems showing a clear picture that the students need to improve their knowledge on the differences between metaphor and simile.
\end{abstract}

\section{Introduction}

Figurative language is a language that uses figurative words in the form of a single word or phrase that has the meaning of special repetition, arrangement or deletion of words with literal meanings. According to Abrams (1981: 63), "Figurative language is a deviation from what is understood by speakers of language as ordinary, or standard, significance or sequence of words, to achieve some special meaning". Many people speaks using emphasis, expression or clarity. Figures of speech portray mental images in words. Alphabet not only describes figures figuratively, but numbers also speak or describe figuratively. It stimulates our imagination and fosters our visual and audio sides. In general, figurative language can be divided into 4 groups, namely: confirmation, comparison, opposition, and figures of speech.

Metaphors are one of the figures that are often used in the context of English. The main key in a metaphor is to use word choices that equate something with something else. In equating or comparing something, the metaphor uses direct comparison without being followed by comparative words like, similar, like ... like, etc.

Metaphor itself is widely used by the wider community, especially students, perhaps because the use of language is easier to understand. Usually, metaphors are used for imaginative ways of describing something by referring to something else that has qualities to express, such as seducing someone we often hear or say statements like "Oh, my love is red, rose red." In this statement, we do not interpret in the true sense but based on equality or comparison, red can be interpreted as the same love with roses. Film can also attract someone's interest to follow interesting things such as advertisements that we can find on banners or electronic media. The complement of language style also can be finding in song lyrics, poetry, etc.

Simile is a figurative language or it can also be called a parable that compares 2 different things using conjunctions (such as or as). Simile has two theories that needed, first, simile requires a general comparison theory and the two similes require differences. It was explained that there are three types of comparative assessment, namely: comparison of open, closed, simple, and closed variables. The difference between a simile comparison and an ordinary comparison is if the simile uses predictive comparisons (predictions are described as subjects) while the usual comparison uses symmetrical comparisons (subject and prediction as independent units).

Based on the introduction, the problems of the research were stated as follows: a) How is the students' understanding on metaphor in English context? b) How is the students' understanding on simile in English context?

\section{Method}

This study conducted a descriptive quantitative study to reveals and seeks for the answers. Descriptive design collect information about variables without changing the environment or manipulating any variables, so they do not look at possible cause and effect. According to Grove, Burns and Gray (2013, p, 215), descriptive designs "May be used to develop theory, identify problems with current 
practice, justify current practice, make judgments or determine what others in similar situations are doing". Besides that, Arikunto (2013) explained that "That descriptive research has no hypothesis but only described some variable and condition naturally". So, this research had a purpose to describe students' understanding on metaphor and simile in English context at the sixth semester students of English Education Department in Universitas Lancang Kuning, especially to the lecturers' semantics class. Moreover, according to Creswell (2003, p. 18), states, quantitative research "Employ strategies of inquiry such as experimental and surveys, and collect data on predetermined instruments that yield statistical data".

Population of this study were the sixth semester of Department of English Education at Faculty of Education and Teachers' Training in Universitas Lancang Kuning. These students were selected due to they already taken a semantic class in the last semester. The class of them were just regular by the total students were 38. According to Creswell (2005:146), "A sample is a subgroup of the target population that researcher plans to study for generalizing about the target population".

If the population is less than 100 people, the sample can be taken all of the population. The technique took the sample is chosen by total, it means, every number of population will be selected. The online test used as the main instrument in this research. The test consisted of 40 items. Google form used to help in gaining the main data to reveals the linguistic phenomenon regarding metaphor and simile.

The form of the test was multiple choice. The researcher use based on syllabus of semantics that consists of five choices; excellent, good, fair, poor and failed. The students able to select one of the answers in multiple choice. Each choice had score to calculate the data from the test. One question value 2,5. The online test can be seen in this following link http://bit.ly/testmetaphorandsimile.

This study will calculated and analyzed the data of the test by using descriptive statistics as in the formulation below:

$$
\begin{aligned}
& \text { Mean }(\mathrm{X})=\frac{\sum \text { Rawsiore }}{N} \\
& \text { Range }(J)=X_{\max }-X_{\min }
\end{aligned}
$$

To strengthen of score above, the researcher would be refer to the Course Grade of Students at Semantics of department Universitas Lancang Kuning to know the level of students' understanding on metaphor and simile in English context. The range of score was represented by the table 2.1 below:
Table 2.1 The Grade Score of Students at Semantics

\begin{tabular}{ccl}
\hline No & Scale & \multicolumn{1}{c}{ Level } \\
\hline 1 & $80-100$ & A: Excellent \\
2 & $70-79$ & B: Good \\
3 & $60-69$ & C: Fair \\
4 & $50-59$ & D: Poor \\
5 & $<49$ & E: Failed \\
\hline
\end{tabular}

\section{Findings}

\subsection{Metaphor}

The researcher had done try out the test for students at the eighth semester of English Education Department in Universitas Lancang Kuning before doing the exact test to samples of this research. The participant of this try out is 30 students in eighth semester of English Education Department in Universitas Lancang Kuning May, 20th 2019, consist of 50 questions. This is needed to measure the level of understanding on metaphor and simile in English context.

Before doing the test, the students in eighth semester of English Education Department in Universitas Lancang Kuning had learnt the Metaphor and Simile in Semantics Major with their lecturer. The researcher tried out the test in order to check the validity and reliability of the test. The students were asked to choose the correct answer for each question.

After finished the test, the researcher tabulated the score of the students' answers to check the validity and reliability by using SPSS version 22 program. Based on the result, the researcher saw that from 50 questions only 48 questions that have been valid. The reliable of the test was 752. It is because the test was valid and reliable.

The researcher did test to sixth semester student of English Education Department in Universitas Lancang Kuning on 27th May, 2019 until 18th June, 2019 to answer the first question in this research, 'How is the students' understanding on metaphor in English context?". The researcher gave 40 questions to 38 sixth semester students of English Education Department in Universitas Lancang Kuning. The researcher only gave 40 questions to the students to get the maximum score. The number of metaphor questions was 20 questions. The researcher shared the form of a test in link to the group class of students in semester $6 \mathrm{~A}$ and $6 \mathrm{~B}$, then the researcher gave instructions to them to choose one of the choices they thought was right. The test consists of 2 indicators: sentences about metaphor and sentences about simile.

After shared the test, the researcher tabulated and calculated the score of the test. The researcher would like to present the data and descriptive statistics from the data. The researcher used mean and range to 
calculated the total of students in each scale of the question. The description of the scores that had already been analysed can be seen in the following table.

Table 3.1 Total Scores of Students

\begin{tabular}{|c|c|c|c|c|c|}
\hline NO & STUDENTS & SCORES & NO & STUDENTS & SCORES \\
\hline 1 & Student 1 & 50 & 1 & Student 13 & 100 \\
\hline 2 & Student 2 & 60 & 2 & Student 15 & 100 \\
\hline 3 & Student 3 & 10 & 3 & Student 25 & 100 \\
\hline 4 & Student 4 & 65 & 4 & Student 28 & 100 \\
\hline 5 & Student 5 & 75 & 5 & Student 34 & 100 \\
\hline 6 & Student 6 & 60 & 6 & Student 36 & 100 \\
\hline 7 & Student 7 & 45 & 7 & Student 18 & 95 \\
\hline 8 & Student 8 & 75 & 8 & Student 22 & 95 \\
\hline 9 & Student 9 & 85 & 9 & Student 9 & 85 \\
\hline 10 & Student 10 & 50 & 10 & Student 5 & 75 \\
\hline 11 & Student 11 & 70 & 11 & Student 8 & 75 \\
\hline 12 & Student 12 & 70 & 12 & Student 24 & 75 \\
\hline 13 & Student 13 & 100 & 13 & Student 11 & 70 \\
\hline 14 & Student 14 & 40 & 14 & Student 12 & 70 \\
\hline 15 & Student 15 & 100 & 15 & Student 21 & 70 \\
\hline 16 & Student 16 & 60 & 16 & Student 4 & 65 \\
\hline 17 & Student 17 & 60 & 17 & Student 2 & 60 \\
\hline 18 & Student 18 & 95 & 18 & Student 6 & 60 \\
\hline 19 & Student 19 & 40 & 19 & Student 16 & 60 \\
\hline 20 & Student 20 & 60 & 20 & Student 17 & 60 \\
\hline 21 & Student 21 & 70 & 21 & Student 20 & 60 \\
\hline 22 & Student 22 & 95 & 22 & Student 26 & 60 \\
\hline 23 & Student 23 & 40 & 23 & Student 38 & 60 \\
\hline 24 & Student 24 & 75 & 24 & Student 30 & 55 \\
\hline 25 & Student 25 & 100 & 25 & Student 1 & 50 \\
\hline 26 & Student 26 & 60 & 26 & Student 10 & 50 \\
\hline 27 & Student 27 & 30 & 27 & Student 7 & 45 \\
\hline 28 & Student 28 & 100 & 28 & Student 14 & 40 \\
\hline 29 & Student 29 & 40 & 29 & Student 19 & 40 \\
\hline 30 & Student 30 & 55 & 30 & Student 23 & 40 \\
\hline 31 & Student 31 & 35 & 31 & Student 29 & 40 \\
\hline 32 & Student 32 & 30 & 32 & Student 33 & 40 \\
\hline 33 & Student 33 & 40 & 33 & Student 35 & 40 \\
\hline 34 & Student 34 & 100 & 34 & Student 37 & 40 \\
\hline 35 & Student 35 & 40 & 35 & Student 31 & 35 \\
\hline 36 & Student 36 & 100 & 36 & Student 27 & 30 \\
\hline 37 & Student 37 & 40 & 37 & Student 32 & 30 \\
\hline 38 & Student 38 & 60 & 38 & Student 3 & 10 \\
\hline & & TOTAL 0F SCORES & & 2380 \\
\hline & & & & 62,63 \\
\hline
\end{tabular}

$$
\begin{aligned}
& \text { Mean }(X)=\frac{\sum \text { Rawsior }}{N}=\frac{2380}{32}=62,63 \\
& \text { Range }(J)=X_{\text {max }}-X_{\min }=100-10=90
\end{aligned}
$$

Based on the table 3.1 above, it can be interpreted that the students' understanding on selected metaphor in English context at sixth semester of English Education Department in Universitas Lancang Kuning. The understanding of the sixth semester of English Education Department in Universitas Lancang Kuning can be categorized into fair. Based on table 4 above, the table showed that the total of raw score of students was 2380 with the mean was 62,63 and the range of the score was 90 with the higher score was 100 and the lowest score was 10 .
Table 3.2 The Classification of Students' Understanding on Metaphor in English Context

\begin{tabular}{|c|c|c|c|}
\hline NO & SCORES & FREQUENCY & CATEGORIES \\
\hline 1 & 100 & 6 & Excellent \\
\hline 2 & 95 & 2 & Excellent \\
\hline 3 & 85 & 1 & Excellent \\
\hline 4 & 75 & 3 & Good \\
\hline 5 & 70 & 3 & Good \\
\hline 6 & 65 & 1 & Fair \\
\hline 7 & 60 & 7 & Fair \\
\hline 8 & 55 & 1 & Poor \\
\hline 9 & 50 & 2 & Poor \\
\hline 10 & 45 & 1 & Failed \\
\hline 11 & 40 & 7 & Failed \\
\hline 12 & 35 & 1 & Failed \\
\hline 13 & 30 & 2 & Failed \\
\hline 14 & 10 & 1 & Failed \\
\hline TOTAL OF STUDENTS & 38 & \\
\hline
\end{tabular}

Based on table 3.2, it showed that there were six students who got 100 , two students got 95 and one student got 85 . It made nine students categorized into excellent. Next, there were three students each got 75 and 70. These six students were on good category. Next, there were one student who got 55 and two students got 50. It made three student categorized into poor. Last, there were one student each got 45, 35 and 10 , seven students who got 40 and two students got 30 . So that, there were twelve students on failed category.

\section{Frequency of Metaphor}

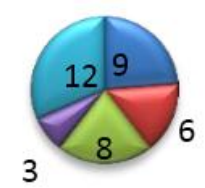

$$
\begin{aligned}
& \text { Excellent } \\
& \text { Good } \\
& \text { Fair }
\end{aligned}
$$

Figure 3.1 Frequency of the Students' Understanding on Metaphor

From the diagram 1 above, it showed that 9 students were categorized into excellent. There were 6 students were categorized into good. 8 students were categorized into fair. 3 students were categorized into poor. 12 students were in failed category. By considering the students' average or mean score, the students' understand on selected metaphor in English context among sixth semester students of English Education Department in Universitas Lancang Kuning was in fair category.

\subsection{Simile}

The researcher did test to sixth semester student of English Education Department in Universitas Lancang Kuning on 27th May, 2019 until 18th June, 2019 to answer the second question in this research, "How is the students' understanding on simile in 
English context?" The researcher gave 40 questions to 38 sixth semester students of English Education Department in Universitas Lancang Kuning. The researcher only gave 40 questions to the students to get the maximum score. The number of simile questions was 20 questions. The researcher shared the form of a test in link to the group class of students in semester $6 \mathrm{~A}$ and $6 \mathrm{~B}$, then the researcher gave instructions to them to choose one of the choices they thought was right. The test consists of 2 indicators: sentences about metaphor and sentences about simile.

After shared the test, the researcher tabulated and calculated the score of the test. The researcher would like to present the data and descriptive statistics from the data. The researcher used mean and range to calculated the total of students in each scale of the question. The description of the scores that had already been analysed can be seen in the following table:

Table 3.3 Total Score of Similes

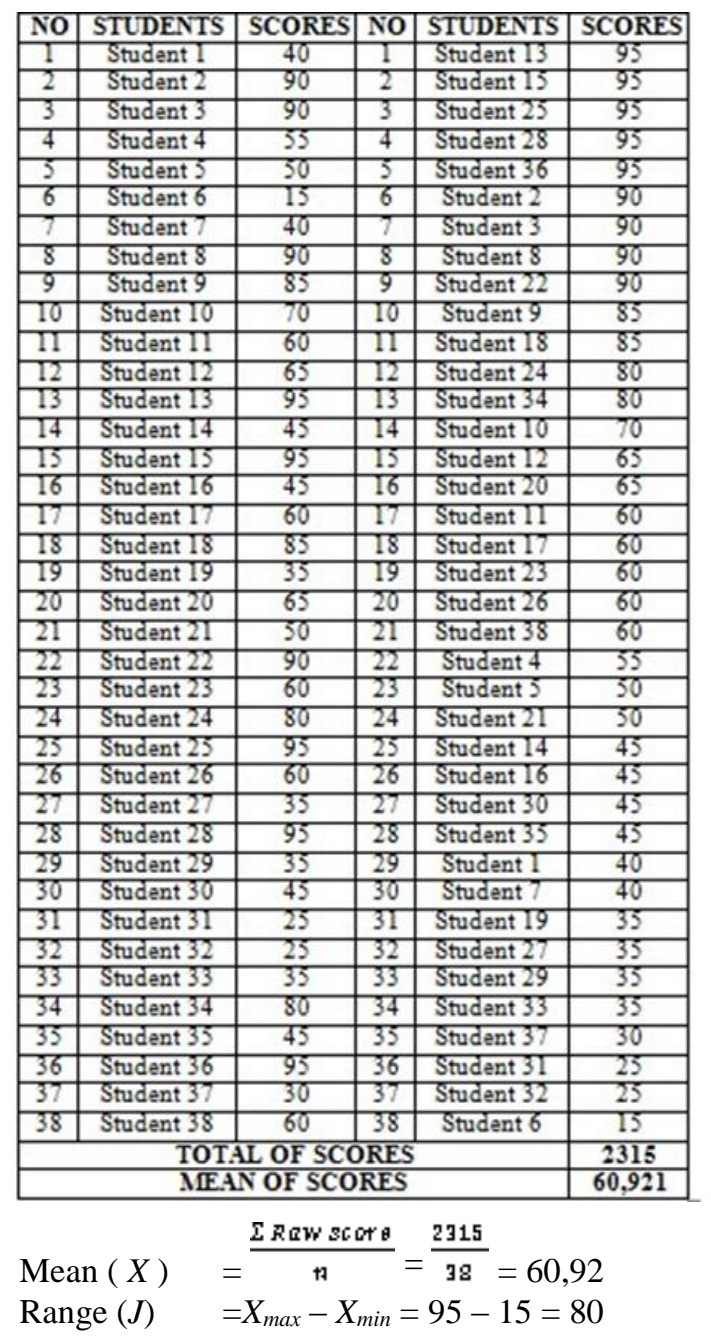

Based on the table 4 above, it can be interpreted that the students' understand on simile in English context at the sixth semester of English Education Department in Universitas Lancang Kuning. The understanding of the sixth semester of English Education Department in Universitas Lancang Kuning can be categorized into fair. Based on table 6 above, the table showed that the total of raw score of students was 2315 with the mean was 60,92 and the range of the score was 80 with the higher score was 95 and the lowest score was 15 .

Table 3.4 The Classification of Students' Understanding on Simile

\begin{tabular}{|c|c|c|c|}
\hline MO & SCORE & FREQENCY & CATEGORY \\
\hline 1 & 95 & 5 & Excellent \\
\hline 2 & 90 & 4 & Excellent \\
\hline 3 & 85 & 2 & Excellent \\
\hline 4 & 80 & 2 & Excellent \\
\hline 5 & 70 & 1 & Good \\
\hline 6 & 65 & 2 & Fair \\
\hline 7 & 60 & 5 & Fair \\
\hline 8 & 55 & 1 & ?oor \\
\hline 9 & 50 & 2 & Poor \\
\hline 10 & 45 & 4 & Failed \\
\hline 11 & 40 & 2 & Failed \\
\hline 12 & 35 & 4 & Faided \\
\hline 13 & 30 & 1 & Failed \\
\hline 14 & 25 & 2 & Failed \\
\hline 15 & 15 & 1 & Failed \\
\hline & TOTAL 0F STDDENS & 38 & \\
\hline
\end{tabular}

Based on the table 5 above, it showed that there were five students who got 95 , four students got 90 and two students each got 85 and 80 . It made thirteen students categorized into excellent. Next, there were one student who got 70 . So, these one student were on good category. Beside that, two students who got 65 and five students got 60 . It made seven students categorized into fair. Next, there were one student got 55 and two students who got 50. So, these three students were on poor category. Last, there were four students each got 45 and 35, two students each got 40 and 25 and one student each got 30 and 15. So that, there were twelve students on failed category.

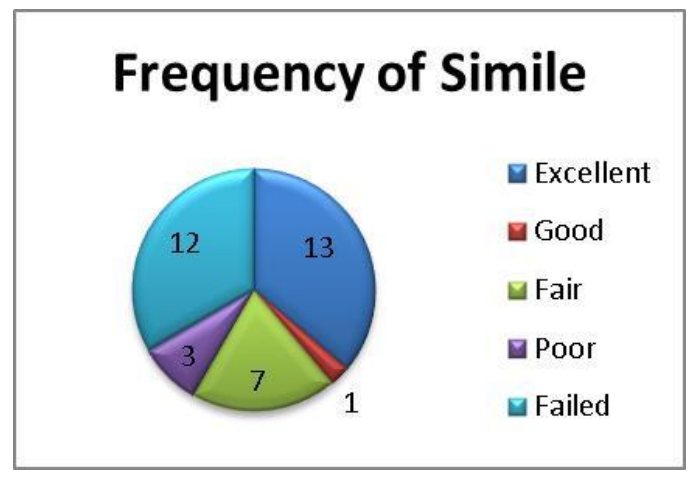

Figure 3.2 Frequency of The Students' Understanding on Simile

From the diagram 2 above, it showed that 13 of the students were categorized into excellent. Another 1 students were categorized into good. 7 of the students 
were categorized into fair. 3 of the students were categorized into poor and 12 of the students were categorized into failed. By considering the students' average or mean score, the students' understand on selected simile in English context at the sixth semester students of English Education Department in Universitas Lancang Kuning was in fair category.

\section{Findings}

Based on the type of cross-sectional survey research designs, the findings of this research has importance to give information or an input such as evaluation for the lectures in teaching semantics especially metaphor and simile. By knowing these errors, the lecturer can use the effective and efficient ways to work on eliminating the students' understanding on metaphor and simile. The findings of this research are hoped to increase the students' achievement in learning semantics especially in using metaphor and simile. The findings of this research can be seen that the mean score of the students' understanding on metaphor was 62,63 and simile was 60,92 . In other words, the students' understanding on metaphor and simile was categorized into fair. In short, this research purposes to give the additional evaluation for the semantics' lecturer in teaching metaphor and simile at Universitas Lancang Kuning.

After all discussion above, what make this research different with all related finding is in accordance with the data analysis done during this research, the researcher found that the students' understanding on metaphor and simile in English context was categorized into fair, willingness revealed together here was that students fulfilled taking test data. Need to add samples to get accurate data one thing that can be exposed together here is students willingness in fulfilling their taking test data.

\section{Conclusion}

This study analysis seen that the the students' understanding on metaphor and simile was categorized into fair. The data reveals the mean score of the students' understanding on metaphor was 62,63 and simile was 60,92. With this findings the study concluded that that the students' understanding on metaphor and simile in English context need to be improved.

\section{Acknowledgement}

The writers give their gratitude to anonymous reviewers and colleague who assisted immensely in the production of this research article, especially for their feedback and critic.

\section{References}

Arikunto. (2013). Prosedur Penelitian: Suatu Pendekatan Praktik. Jakarta: Rineka Cipata.
Brown, F. B. (2018). Transfiguration: Poetic metaphor and the languages of religious belief. UNC Press Books.

Creswell, W. Jhon. (2003). Research design: Qualitative, quantitative and mixed methods approaches (2nd ed.). Thousand Oaks, CA: SAGE Publications.

Creswell, W. Jhon. (2005). Educational Research Planning, Conducting and Evaluating

Quantitative and Qualitative Research. Second Edition. New York: University of NebraskaLincoln.

Delfino, M., \& Manca, S. (2007). The expression of social presence through the use of figurative language in a web-based learning environment. Computers in Human Behavior, 23(5), 21902211.

Gibbs RW (1994). The Poetics of Mind. Cambridge, UK: Cambridge University Press.

Grove, S. K., Burns, N., \& Gray, J. R. 2013. The practice of nursing research: Appraisal, synthesis, and generation of evidence. St. Louis, MO: Elsevier Saunders.

Honeck, R. P., \& Hoffman, R. R. (Eds.). (2018). Cognition and figurative language. Routledge.

Lodge, D. (2015). The modes of modern writing: metaphor, metonymy, and the typology of modern literature. Bloomsbury Publishing.

Métraux, J. C., \& Furtos, J. (2011). La migration comme métaphore. La dispute.

Mio, J. S. (2018). Metaphor, politics, and persuasion. In Metaphor (pp. 127-146). Psychology Press.

Ortony A (1993). Metaphor and Thought. (2nd ed.). New York: Cambridge University Press.

Pollio, H. R. (2018). Boundaries in humor and metaphor. In Metaphor (pp. 231-253). Psychology Press.

Radman, Z. (Ed.). (2015). From a metaphorical point of view: a multidisciplinary approach to the cognitive content of metaphor (Vol. 7). Walter de Gruyter GmbH \& Co KG.

Ricoeur, P. (2004). The Rule of Metaphor. The Creation of Meaning in Language. Routledge, London and New York.

Sörensen, K. (2015). Metaheuristics - the metaphor exposed. International Transactions in Operational Research, 22(1), 3-18.

Steen, G. (2015). Developing, testing and interpreting deliberate metaphor theory. Journal of Pragmatics, 90, 67-72. 
Wałaszewska, E., (2013). Like in similes-are levance-theoretic view. Res. Lang. $11(3), 323334$.

Yan Xu. (2015). Implication of Metaphor in Language Teaching. International Conference on Arts, Design and Contemporary Education (ICADCE)

Yeibo, E. (2012). Figurative Language and Stylistic Function in JP Clark-Bekederemo's Poetry. Journal of Language Teaching \& Research, $3(1)$. 